\section{International Scientific Journal Theoretical \& Applied Science}

p-ISSN: 2308-4944 (print) e-ISSN: 2409-0085 (online)

Year: $2015 \quad$ Issue: 03 Volume: 23

Published: $30.03 .2015 \quad$ http://T-Science.org

SECTION 32. Jurisprudence.
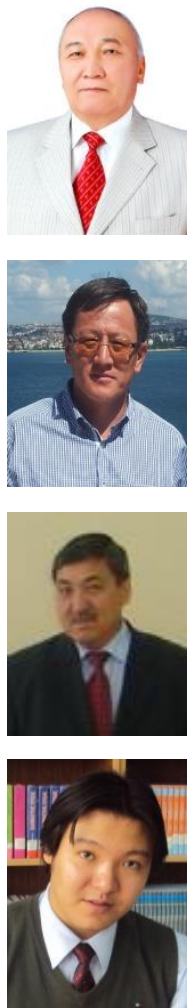

Balgabay Isakulovich Nakipov Doctor of Law Science, Professor of IKTU

Department of Strategic Planning of

Scientific-Research Developments, International Kazakh-Turkish University by name of Yassavi, Kazakhstan

Nurlan Muhtarovich Batyrbaev

Candidate of Law Science, professor

Department of Strategic Planning of

Scientific-Research Developments International Kazakh-Turkish University by name of Yassavi, Kazakhstan Kuanyshbek Baimbetovich Urazbayev Candidate of Philological Sciences, Associate Professor,

Expert in the English Terminology English Philology Department,

Yassawi University, Kazakhstan

Yernar Sailaubekovich Shalkharov $\mathrm{PhD}$ in law Science

Department of Strategic Planning of Scientific-Research Developments International Kazakh-Turkish University by name of Yassavi yernar_shalkharov@bk.ru

\title{
PERSPECTIVE OF THEORETICAL CONSIDERATION IN THE TEXT OF THE ARTICLE "CLONING OF THE PERSON" OF THE NEW CRIMINAL CODE OF THE REPUBLIC OF KAZAKHSTAN FROM THE POSITION OF THE INTERNATIONAL AND FOREIGN EXPERIENCE OF COUNTRIES OF WESTERN EUROPE IN PARTICULAR THE UNITED KINGDOM: COMPARATIVE ANALYSIS
}

\footnotetext{
Abstract: In the present article all three main arguments which can complicate the realization mechanism in content of the article of the Criminal Code of the Republic of Kazakhstan "cloning of the person" have been provided. These arguments are: perspective of classification of a crime, perspective of a legal imbalance and legal factor.

Key words: Criminal Code, Kazakhstan, human cloning, crime, legal imbalance.

Language: English

Citation: Nakipov BI, Batyrbaev NM, Urazbayev KB, Shalkharov YS (2015) PERSPECTIVE OF THEORETICAL CONSIDERATION IN THE TEXT OF THE ARTICLE "CLONING OF THE PERSON" OF THE NEW CRIMINAL CODE OF THE REPUBLIC OF KAZAKHSTAN FROM THE POSITION OF THE INTERNATIONAL AND FOREIGN EXPERIENCE OF COUNTRIES OF WESTERN EUROPE IN PARTICULAR THE UNITED KINGDOM: COMPARATIVE ANALYSIS. ISJ Theoretical \& Applied Science 03 (23): 138-145.
}

Soi: http://s-o-i.org/1.1/TAS*03(23)24 Doi: crossef http://dx.doi.org/10.15863/TAS.2015.03.23.24

\section{Introducton.}

Today is a very emerging field of genetic engineering is the issue of cloning. Speaking about the nature of cloning this term can be identified as receiving multiple identical copies of hereditary molecules (molecular cloning). In practice, this act was implemented in July 1996. It was the first precedent cloning of a mammal some animal - sheep Dolly. Following delivered over now, the issue of cloning is investigated by scientists from different countries by opening and development of specialized laboratory facilities on the clone. The ultimate goal of this direction is human cloning. However, how 
will this affect the legislative level and is a matter of discussion of this article [1].

\section{PERSPECTIVE OF CLASSIFICATION OF THE CRIME.}

Today the article of human cloning has been issued in the Criminal Code of the Republic of Kazakhstan. So, in compliance with part 1 of article 129 of the Criminal Code of the Republic of Kazakhstan "cloning of the person or use of a human embryo for the commercial, military and industrial purposes, and equally export of gametes or a human embryo from the Republic of Kazakhstan in the same purposes are punished by imprisonment for a period of up to three years with deprivation of the right to hold certain positions or to be engaged in a certain activity for a period of up to two years and without that" [2]. Certainly, the innovative direction in criminal policy, is break in system of classification of crimes. However, there are problems to which the real system isn't ready in theoretical, on the practical level [3].

As the first problem it is possible to allocate procedure of identification of a crime. Today in Kazakhstan there is only one way of identification of a crime - on composition. In line with this way of detecting crimes in composition to the subject of crime are individuals who have specialized education and skills for the implementation of particularly complex artificial manipulation at the genetic level to create the sample person absolutely identical subject.

The subjective side, it is possible to assume a scientific or financial interest of the researcher engaged in such practices. At this scale of public danger of the crime is quite high, as it can cause severe consequences. Thus the fault is classified as intention as this crime committed on imprudence contradicts logic and common sense. Thus, the intentional commission of such genetic manipulation implies the recognition guilty of an entity committed acts, foresight of its consequences, and existence of the will, directed to its commission. As the object can be considered social value who are harmed. Basically this judgment applies to the ethical standards of morality and ethics. Keen interest and motivation pushing the subject to commit this crime is the objective side, where the researcher has been engaged in human cloning feels a sense of creativity and even at some of the role of arousal in the process of this experiment [4].

Identification of such crime as "human cloning" on crime is quite informative, but not effective, based largely on the fact that the public authorities having happened before in the territory of the Republic of Kazakhstan were not recorded. However, for such crimes can be effective the European methods of classification of crimes [5]. The famous English jurist Stephen in his "Commentaries on the laws of
England" gave the following explanation of the concept of crime: "Crime is any violation of law considered from the standpoint of harmful orientation (evil tendency) of such violation against society as a whole" [6]. Another, more detailed wording of the offence is the following: "A crime or criminal offence is the harm prohibited by law, regardless of whether it is also a tort, breach of contract or breach of confidence, the main consequence of which is that the offender, if found and is subject to criminal liability, prosecuted on behalf of the state and, if found guilty, shall be punished" [7].

The classification of crimes in English law covers three key signs: 1) sources of criminal responsibility; 2) significance of the object encroachment; 3 ) according to the degree of danger of the crime. This method of classification inherent in the majority of lawyers of England [8]. In accordance with sources, the criminal liability of all criminal acts are divided into crimes under common law and statutory. This classification proceeds from legal traditions of England and specifics of the Anglo-Saxon law in which the bigger place is given to judicial precedents and customs, than to the codified norms (in many branches the level of English law codification is still very low and when considering a particular case the judge is forced to go to a huge archive of similar cases to make a fair decision) [9]. In spite of the fact that many provisions of criminal law of England are already codified and sources of legal responsibility for many offenses are statutes (regulations), many serious crimes as murder, haven't found the reflection in the hand-written legislation yet and still are crimes on the general (case) law [10]. In modern criminal and legal practice of England the tendency of increase in a share of statute crimes is observed as more and more new types of criminal liability finds the reflection in the codified statutes [11].

Depending on the importance of object, crimes are classified in the criminal and legal doctrine of England since classifications of crimes by this sign at the legislative level haven't been carried out [12]. Different jurists of England give the following types of crimes depending on the importance of their object: crimes against the personality, crimes against property, crimes against a public order, political crimes, sexual crimes, crimes against public morals, motor transportation crimes, crimes against justice, computer crimes, etc. and so on [13]. In England, before adoption of law on Criminal Law of 1967, a crime were classified by degree of danger on especially dangerous (treason and phelonia) and less dangerous (misdiminor) crimes [14]. Felonies were allocated as the most serious crimes which obligatory consequence was confiscation of property. Heavy 
and simple murder, a robbery and stealing of property, polygamy and rape belonged to a phelonion. Depending on the degree of tagaste of a crime classified as a chasuble, changing the degree of punishment, although in the past all these crimes were punishable by death [15]. Treason as one of types of serious crimes in the English law, was subdivided into state (high treason) (attempt at the king or the member of his family, counterfeiting and a fake of the royal seal, murder of the chancellor or judges) and small (petty treason) (murder of the husband by the wife or owner's servant). Now treason only high treason is considered [16]. For less serious crimes were misdemeanors, which included fraud, theft, perjury, deception, etc. For misdemeanours, the defendant was never subjected to the death penalty and its assets are not always confiscated. The division of crimes on phelonia and misdemeanors was cancelled by the law on criminal law of 1967. Now crimes in England are classified according to the degree of tagaste for high treason and other crimes [17].

The above-stated classification of crimes by degree of danger proceeded from the material and legal point of view. From the procedural point of view (on a way of legal proceedings) crimes are subdivided by the English law for the following:

- The acts pursued under the indictment (these crimes are dealt with in Crown court, consisting of judges and jurors, which is preceded by a hearing in the magistrate's court, revealing the sufficiency of the evidence and the validity of the charges).

- Total crimes are the crimes considered by magistrate's court without participation of jurors. Case is considered by this instance from beginning to end without preliminary investigation.

- The mixed or hybrid crimes are crimes which can are considered in one of above-mentioned orders for choice. These offences are established by the statutes, and the last possibility on the consideration of the offence on indictment and in total order. The trial method is determined by the mixed affairs by magistrate's court [17].

The law of 1967 also introduced classification of crimes on detentioned and non-detentioned. In a case with the first type of crimes, the constable or the individual can make arrest of the criminal without the relevant decision of the judge. There are two criteria of belonging of a crime to arested type:

1. The crime has to be subject to punishment, strictly defined in the law (the death penalty or life imprisonment);

2. The crime must promise not previously convicted person for at least five years of imprisonment.

All other crimes are among the non-detentioned. Here implementation of arrest requires the special decision of the judge. In some cases, the law does permit contrary, but subject to certain conditions [17].

Thus, it is possible to note that commission by the natural person of the crime classified by the criminal legislation of the Republic of Kazakhstan as "cloning of the person" the most correct will classify by the British model where on sources of emergence of criminal liability this crime will be the codified statute. That is the standard provision on nature of perfect illegal act fixed at the legislative level. In this case in the British legislation there has specifically expressed which subject commits this sort a crime: geneticists, biologists, microbiologists, molecular experts, and biotechnologies experts [18]. Depending on the importance of object of a crime much more correct will classify it also by the British model as a crime against public morals. In the Kazakhstan legislation the crime is classified as criminal offenses against the personality. However the clone which is allegedly affected party in this conflict logically can't officially make out the requirements in judicial authorities of the Republic of Kazakhstan against the founders that is not only anti-logical and inconceivable and highly ethical touching on theological issues which and so at the moment are in crisis owing to an anti-extremism state program [19]. On a gravity of offense this offense can be carried to felonies as this act is characterized by the increased public danger with the unpredictable consequences capable to do harm not only to natural persons but also a social, demographic and ethical situation in society [4]. Thus, it is possible to note that for introduction of such innovative articles in the criminal legislation of the Republic of Kazakhstan it is necessary to consider first of all system of classification of criminal offenses as the former model based on identification of structure of crimes remained far in the past, outside logical sense.

\section{ISSUES OF LEGAL IRREGULARITY.}

As the second problem of realization of justice on "human cloning" is the imbalance internally of public and international conflict of laws rules. As for example in the Republic of Kazakhstan the criminal code has big validity if the contract even international ratified one though the Republic of Kazakhstan owing to maneuvering in the international space has one of priorities to support policy of the UN concerning cloning of human individuals.

The agenda of the 57th session of the United Nations General Assembly included the point of "International Convention against Cloning of the Person for Reproduction". The relevant resolution was adopted by UN member states unanimously. Thus, universal character of a problem of cloning and need of its international legal regulation received the 
unconditional confirmation. Competence of General Assembly in this case was caused by versatility of this problem which can't be considered in all its aspects within one of specialized institutions of the UN [20].

At the international level the revolutionary document having huge value in the history and development of modern science in legal aspect was agreed on March 8, 2005. It was the declaration of General Assembly of the United Nations "about cloning of the person", taken by the resolution of the United Nations General Assembly for No. 59/280 of March 8, 2005 [21]. In the present document being guided by the purposes and the principles of the Charter of the United Nations, referring to the Universal declaration on human genome and human rights adopted by General conference of the United Nations concerning education, science and culture on November 11, 1997, and, in particular, on its article 11 in which it is said that the practice contradicting human dignity such as practice of cloning for reproduction of a human individual, isn't allowed [22]. Also in the main meeting there were announced the following requirements, obligatory for execution by all member States. These requirements are:

a) the member States are called upon to adopt all measures necessary to protect adequately human life in the application of biological sciences;

b) the member States are called upon to prohibit all forms of human cloning inasmuch as they are incompatible with human dignity and the protection of human life;

c) the member States are further called upon to take measures necessary to prohibit the use of genetic engineering techniques that may be contrary to human dignity;

d) the member States are called upon to take measures to prevent the exploitation of women in the process of applying biological sciences;

$e$ ) the member States are also called upon to urgently adopt and implement national legislation to ensure compliance with paragraphs $(a)-(d)$;

$f)$ the member States are further called upon in the financing of medical research, including the biological sciences, to consider urgent global problems such as HIV/AIDS, tuberculosis and malaria, which are particularly harmful to developing countries.

Thus on the basis of this normative element of internationality we can safely assume that human cloning is regarded in the international community as a violation of human dignity [20].

In the universal Declaration on the human genome and human rights had been achieved balance between respect for human rights and fundamental freedoms with regard to the need to ensure the freedom of research. The Declaration recognized the human genome is the basis of the original unity of all members of the human race, the recognition of their inherent dignity and diversity. The most important position, no doubt, is the assertion that the human genome marks the heritage of mankind [22].

European Convention for the protection of human rights and Biomedicine and the universal Declaration on the human genome and human rights was an important step towards international legal regulation of the problem of cloning. However, the development of norms of universal character, guaranteeing worldwide protection of human rights and dignity in the context of research in the field of cloning and its practical application is possible only with the participation of the entire international community, that is, in the framework of the UN [23].

The UN, including almost all countries in the world, was created as a forum where all Nations can join together to address global issues affecting the interests of all peoples, of all mankind. If, proceeding from definition of the Universal declaration on human genome and human rights to agree that human genome is the cornerstone of an initial community of all representatives of the human race and the property of mankind marks, it inevitably involves recognition of need of the solution of the questions connected with genetic researches at the global level [24].

Within a problem of cloning it is possible to allocate some subtotals. The first is cloning of animals. The second is cloning of the person. The last, in turn, has two more aspects: cloning of human cells, bodies and fabrics and cloning of the person in the reproductive purposes [24].

But for a more thorough analysis of international conventions, it is first necessary to consider the development of cloning in a particular area. Only then, realizing the origins of development problems can be defined as the problem of classification of this crime, but his actions in the international space. This aspect is the third problem the problems of applied factor.

\section{PERSPECTIVE OF APPLIED FACTOR.}

As modern society develops very rapidly, at the same time, improvements in technical capabilities, to lawyers who appear every time new and new problems that must be resolved not only subject to the provisions of the law, and ethical standards [25].

On the one hand, the possibility of cloning has provided ample opportunities for further medical experiments and might help solve the problem of old age, chronic diseases, would talk about the extension of human life [26].

However, these opportunities are not comparable with those moral issues that would put not only the common man but also the lawyer to a 
standstill. As a result of cloning actually receives artificial living organism, like two drops of water similar to the prototype [27].

Lawyers are hard to solve the issue of prohibition or permission of the procedure, legal regulation of the procedure of cloning and further the life of the clones [28].

The term cloning is first applied microbiologists, plant breeders, and then by inheritance was transferred to geneticists. It denotes an exact reproduction of a certain object, which can be repeated an infinite number of times. The resulting objects can be called clones [29].

According to scientists, in the case of man, not all physical characteristics are the same. In particular the prototype and the clone will have different capillary patterns on the fingers [30].

It is necessary to notice that the cloning of the person with reproductive function causes a smaller public response, than cloning with the therapeutic purpose. In the second case, the embryo of a clone is grown up before two weeks, and then its

\section{BACKGROUND}

In the background we'd like to pay more attention that all researches and its results are impossible without such enormous support of our scientific team including Balgabay Isakulovich Nakipov as a coordinator of Perspective Planning, development is stopped. The turned-out material is used for withdrawal of stem cells [31].

Why is the material? It is believed that two weeks is the period during which the identity of the man has not yet begun to emerge. In other words the fourteen day embryo is not human, and material that can be used for medical purposes [32].

It is noteworthy that in different countries the population estimates in different ways the problem of cloning. If in America the majority of the population (almost $70 \%$ ) are in favour of the possibility of therapeutic cloning in the post-Soviet countries slightly more than half of the respondents belong to this process negatively [33].

Also in the post-Soviet countries at the moment the current is the prohibition of human cloning. This legal aspect in the Republic of Kazakhstan adopted relatively recently from 01 January 2015 No. in the criminal code of the Republic of Kazakhstan [34].

Today on the cloning of human beings there is no formal ban in the US and the UK. In the U.S., therapeutic cloning is permitted, and in the UK - the cloning of embryos for medical research [35].

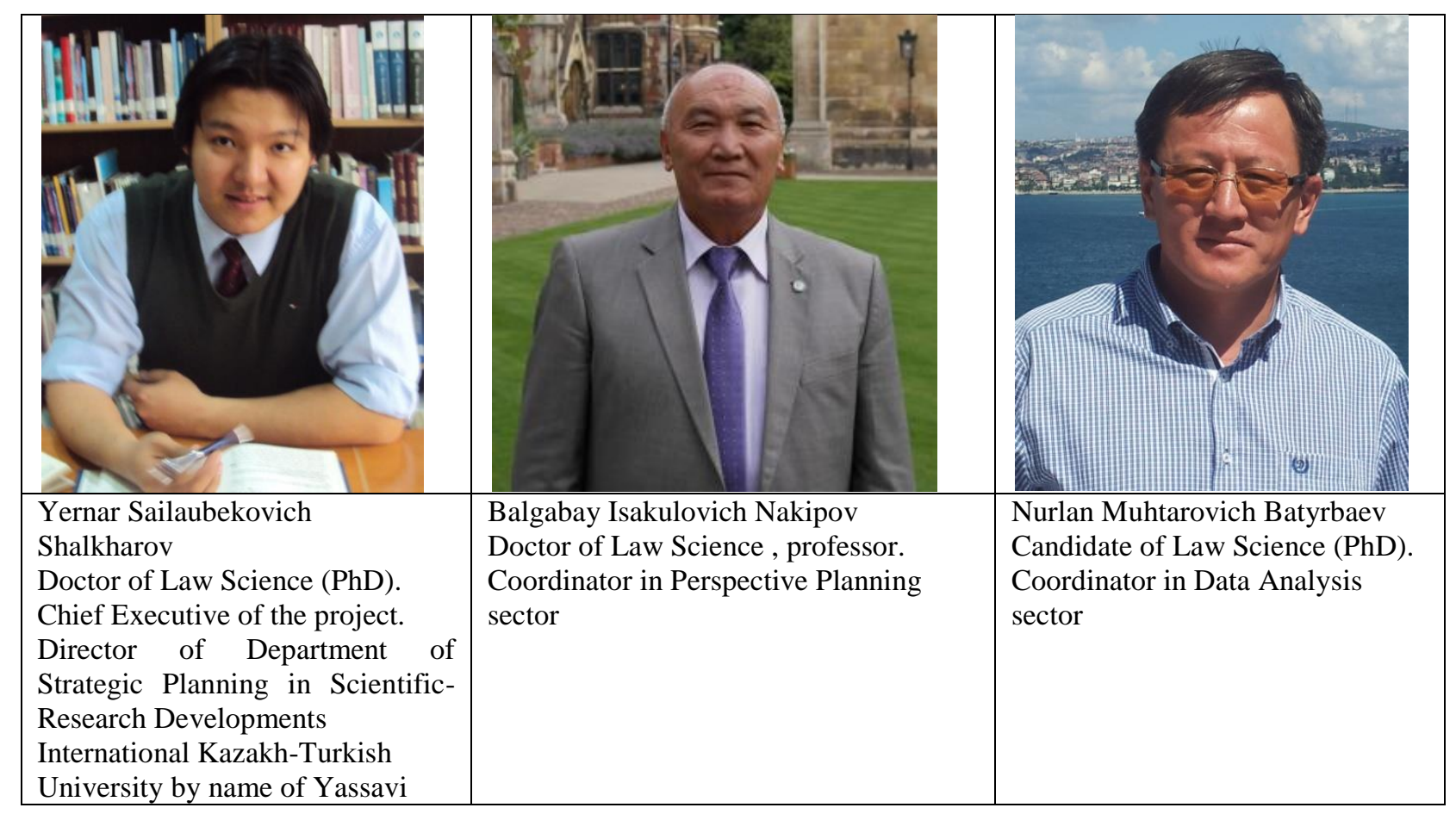

Nurlan Muhtarovich Batyrbaev as a coordinator in Data Analysis Sector, Urazbayev Kuanyshbek Baimbetovich as an expert in interdisciplinary special terminology sector and Luisa Olliviere as Coordinator in Laboratorial Results Sector

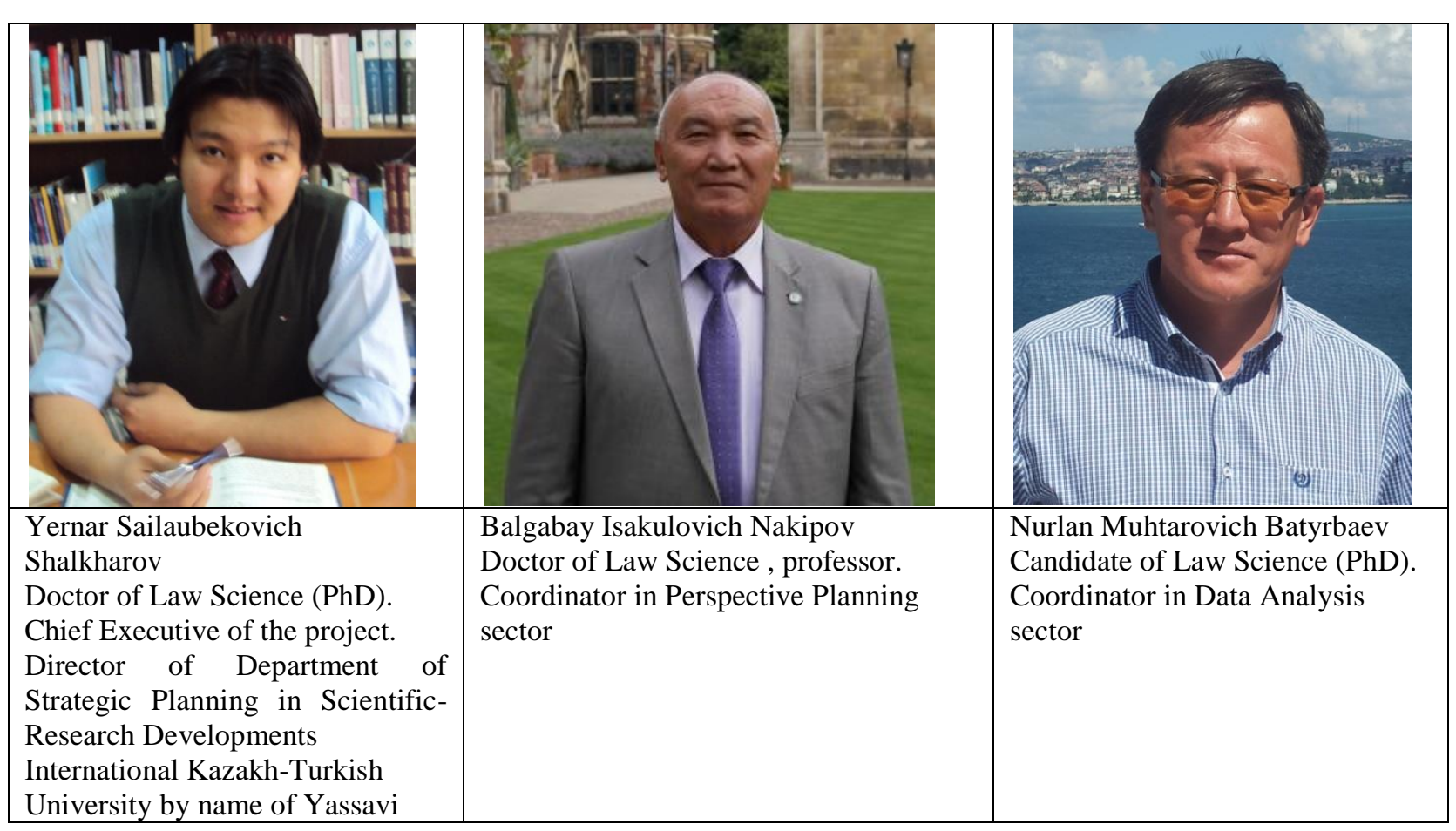




\begin{tabular}{|l|l|l|}
\hline & \\
\hline
\end{tabular}

\section{References:}

1. Posłuszna Elżbieta (2015) 8 - Violence in Defense of the Environment. Environmental and Animal Rights Extremism, Terrorism, and National Security, 2015, pp. 131-151.

2. Calvin Simerly, Masahito Tachibana, Shoukhrat Mitalipov, Gerald Schatten (2014) Chapter 23 Cloning Primates. Principles of Cloning (Second Edition), 2014, pp. 299-310.

3. Ellen R. Wald (2014) Chapter 38 - Urethritis. Feigin and Cherry's Textbook of Pediatric Infectious Diseases (Seventh Edition), Volume 1, 2014, pp. 530-535.

4. Yernar Sailaubekovich Shalkharov, Erkin Shajaevich Dusipov; Nurlan Muhtarovich Batyrbaev; Nurlybek Nurlanovich Uderbaev (2015) APPLIED ASPECTS OF APPLICATION OF INSURANCEOF PROFESSIONAL RESPONSIBILITY OF DOCTOR IN MEDICAL CONFLICTS AND AFFECTING MECHANISMS ON AREA OF PROSECUTION IN KAZAKHSTAN REPUBLIC, CENTRAL ASIA: DISCRIPTIVE APPROACH Published by International Academy of Theoretical \& Applied Sciences, pISSN: 2308-4944. ISJ Theoretical \& Applied Science, issue 1 volime 21, year 2015. Soi: http://s-o-i.org/1.1/TAS*01(21)16

5. Yernar Sailaubekovich Shalkharov, Aktolkyn Koshkarbaevna Moldalieva; Kairat Turlybaevich Bitemirov (2015) VARIETY OF

\section{NECESSITY OF DIVIDING LEGAL CROSS- SECTIONS INTO SEGMENTED SPECIALTIES IN LAW EDUCATION} SYSTEM. Published by International Academy of Theoretical \& Applied Sciences, p-ISSN: 2308-4944. ISJ Theoretical \& Applied Science, issue 1 volime 21, year 2015. pp. 121-125. Soi: http://s-o-i.org/1.1/TAS*01(21)20

6. (2015) The concept of Crime in the Legislation of European Countries. Available: http://www.km.ru/referats/3E9FF4D4BC09497 EAC8E206A894C7007 (Accessed: 20.03.2015).

7. Tetsuya Kobayashi, Makoto Yokota, Tomoaki Mitani, Atsushi Akane (1999) Effects of solvent displacement on sensitivity and specificity of monoclonal antibodies for $\mathrm{ABO}$ blood grouping of forensic specimens with an absorptionelution test. Original Research Article. Legal Medicine, Volume 1, Issue 2, April 1999, pp. 68-75.

8. P. Felker, D. Medina, C. Soulier, G. Velicce, M. Velarde, C. Gonzalez (2005) A survey of environmental and biological factors (Azospirillum spp, Agrobacterium rhizogenes, Pseudomonas aurantiaca) for their influence in rooting cuttings of Prosopis alba clones. Original Research Article. Journal of Arid Environments, Volume 61, Issue 2, April 2005, pp. 227-247. 
9. Filiz Nuran Acar, Zeynep Eren (2006) Removal of $\mathrm{Cu}(\mathrm{II})$ ions by activated poplar sawdust (Samsun Clone) from aqueous solutions. Original Research Article. Journal of Hazardous Materials, Volume 137, Issue 2, 21 September 2006, pp. 909-914.

10. Rubén Lisker (2003) Ethical and legal issues in therapeutic cloning and the study of stem cells. Review Article. Archives of Medical Research, Volume 34, Issue 6, NovemberDecember 2003, pp. 607-611.

11. Vittorio Sgaramella (1993) Lawyers' delights and geneticists' nightmares: at forty, the double helix shows some wrinkles. Original Research Article. Gene, Volume 135, Issues 1-2, 15 December 1993, pp. 299-302.

12. Morris B. Fiddler, Pinar Bayrak-Toydemir, E. Pergament (2002) To clone or not to clone: Who will answer the question? Differentiation, Volume 69, Issues 4-5, January 2002, pp. 182-183.

13. Alessandro Bartoloni, Eleonora Riccobono, Donata Magnelli, Ana Liz Villagran, Tiziana Di Maggio, Antonia Mantella, Samanta Sennati, Carmen Revollo, Marianne Strohmeyer, Tommaso Giani, Lucia Pallecchi, Gian Maria Rossolini (2015) Methicillinresistant Staphylococcus aureus in hospitalized patient from the Bolivian Chaco. Original Research Article. International Journal of Infectious Diseases, Volume 30, January 2015, pp. 156-160.

14. W. Bodmer (2013) Human Genome Project. Reference Module in Biomedical Sciences, from Brenner's Encyclopedia of Genetics (Second Edition), 2013, pp. 552-554, Current as of 1 May 2014.

15. Diana L Deadrick, R.Bruce McAfee (2001) Service with a smile: Legal and emotional issues. Original Research Article//Journal of Quality Management, Volume 6, Issue 1, 4th Quarter 2001, pp. 99-110.

16. Ronald M. Green (2011) Chapter 61 - Ethical Considerations*. Principles of Regenerative Medicine (Second edition), 2011, pp. 11171130.

17. (1967) Law "About Criminal Law".

18. (2015) UK Criminal law

19. Yernar Sailaubekovich Shalkharov, Shamuhamet Nurmuhamedovich Akmadov; Nurlan Muhtarovich Batyrbaev (2015) PROBLEMS OF CONSUMER PROTECTION LEGISLATION IN THE SPHERE OF MEDICALEDUCATION SYSTEM AS A COURSE TO ACHIEVE GOAL OF CORRECT CONNECTION BETWEEN

DOCTOR AND PATIENT IN

KAZAKHSTAN, CENTRAL ASIA

(DISCRIPTING APPROACH) Published by International Academy of Theoretical \& Applied Sciences. ISJ Theoretical \& Applied Science, issue 1 volime 21, year 2015. pp. 126128. Soi: http://s-o-i.org/1.1/TAS*01(21) 21

20. (2015) Materials of the 57th session of the United Nations General Assembly.

21.(2005) The Declaration of the General Assembly of the United Nations on human cloning", adopted by resolution of the UN General Assembly No. 59/280, dated 8 March 2005

22. (2015) The universal Declaration on the human genome and human rights.

23. (2015) European Convention for the protection of human rights and Biomedicine

24. Akiyoshi Tamura, Hiroko Tsuji, Hajime Nishio, Koichi Suzuki (1999) Haplotype analysis of a de novo allele at a vWF STR locus using flanking STR loci Legal Medicine, Volume 1, Issue 3, September 1999, pp. 188-192.

25. Grigorios Leon, Angela Papetta, Chara Spiliopoulou (2011) Overview of the Greek legislation regarding assisted reproduction and comparison with the EU legal framework Reproductive BioMedicine Online, Volume 23, Issue 7, December 2011, pp. 820-823.

26. Ronald J Trent (2005) 10 - Ethical, Legal and Social Implications. Molecular Medicine (Third Edition), 2005, pp. 237-257.

27. Steven B. Davis, W. Joseph Price (2008) Security issues for third party games: Technical, business and legal perspectives. Original Research Article. Computer Law \& Security Review, Volume 24, Issue 2, 2008, pp. 163-168.

28. John Sammons (2012) Chapter 7 - Legal. The Basics of Digital Forensics, 2012, pp. 103-115.

29. Lauren McCain (2002) Informing technology policy decisions: the US Human Genome Project's ethical, legal, and social implications programs as a critical case. Original Research Article. Technology in Society, Volume 24, Issues 1-2, 2002, pp. 111-132.

30. Andrew W. Taylor-Robinson, Simon Walton, David L. Swain, Kerry B. Walsh, Gábor Vajta (2014) The potential for modification in cloning and vitrification technology to enhance genetic progress in beef cattle in Northern Australia. Review Article. Animal Reproduction Science, Volume 148, Issues 3-4, August 2014, pp. 91-96.

31. Ronald M. Green (2014) Chapter 40 - Ethical Implications of Reproductive Cloning. Principles of Cloning (Second Edition), 2014, pp. 497-505.

32. Peter Francis (2001) Legal issues relating to a cardiac surgery database. Original Research 
Article. Heart, Lung and Circulation, Volume 10, Issue 1, 2001, pp. S14-S17.

33. Warren B. Chik (2011) The Google conundrum: Perpetrator or facilitator on the net? - Forging a fair copyright framework of rights, liability and responsibility in response to search engine 2.0 - Part I: The Google Images Search Engine. Original Research Article. Computer Law \& Security Review, Volume 27, Issue 2, April 2011, pp. 111-132.

34. Stefano Solarino (2015) Chapter 9 - Ethical Behavior in Relation to the Scholarly
Community: A Discussion on Plagiarism. Geoethics, 2015, pp. 95-106.

35. Vendula Belackova, Nicole Maalsté, Tomas Zabransky, Jean Paul Grund (2015) "Should I Buy or Should I Grow?" How drug policy institutions and drug market transaction costs shape the decision to self-supply with cannabis in the Netherlands and the Czech Republic. Original Research Article. International Journal of Drug Policy, Volume 26, Issue 3, March 2015, pp. 296-310. 